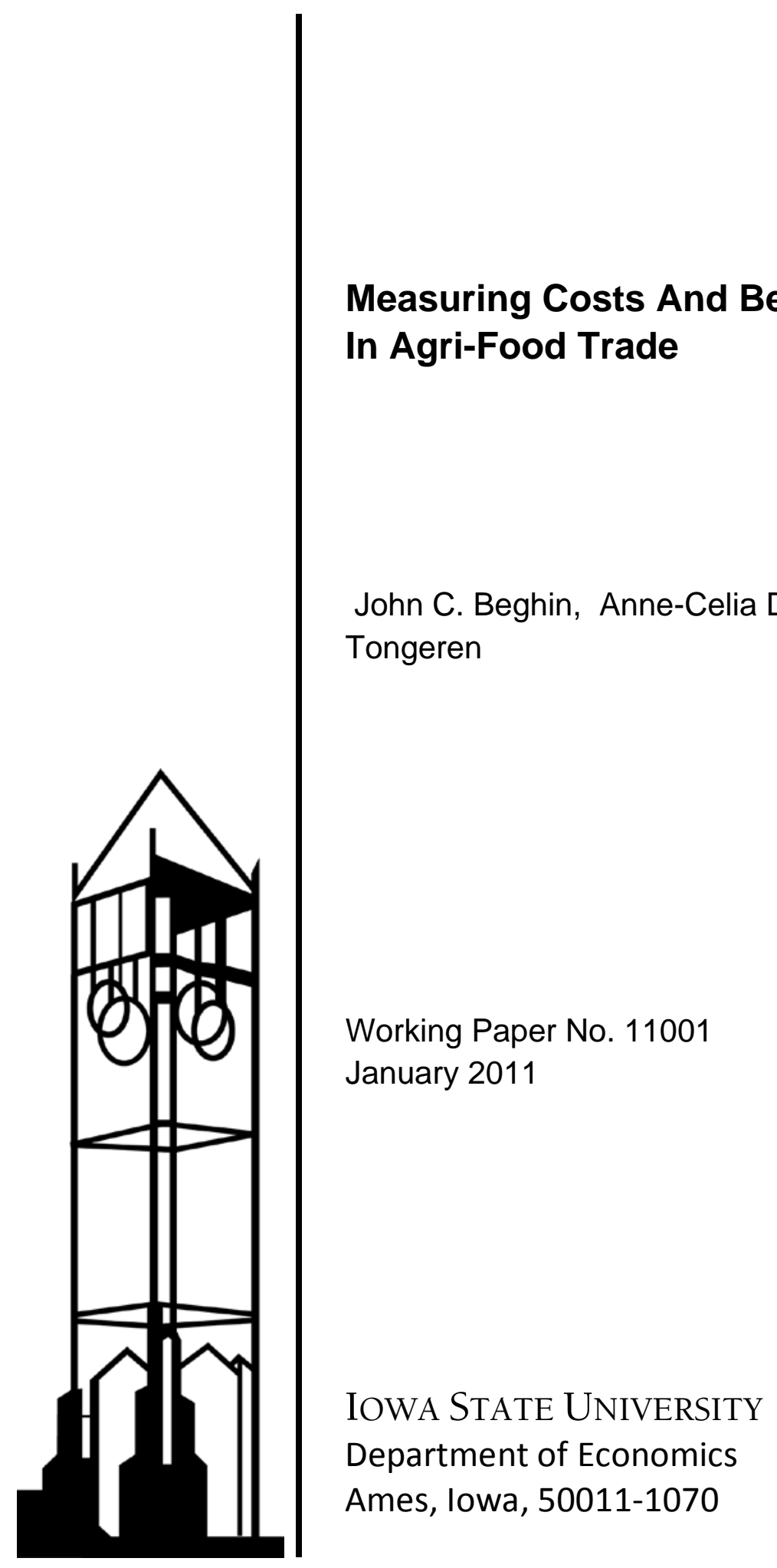

lowa State University does not discriminate on the basis of race, color, age, religion, national origin, sexual orientation, gender identity, sex, marital status, disability, or status as a U.S. veteran. Inquiries can be directed to the Director of Equal Opportunity and Diversity, 3680 Beardshear Hall, (515) 294-7612. 


\title{
MEASURING COSTS AND BENEFITS OF NON-TARIFF MEASURES IN AGRI-FOOD TRADE
}

\author{
John Beghin*, Anne-Célia Disdier\#, Stéphan Marette”, Frank van Tongeren **
}

This draft: January 24, 2011

\begin{abstract}
This paper provides a systematic welfare-based approach to analyze the impact of non-tariff measures (NTMs) on trade and welfare in presence of market imperfections. We focus on standard-like measures such as technical barriers and sanitary and phytosanitary regulations. The approach overcomes the shortcomings of the mainstream approach based on the analysis of forgone trade caused by trade costs. The latter ignores market imperfections: welfare increases when NTMs are removed and trade expands. We explain how to account for external effects and market failures in trade-focused welfare analysis, leading to a more balanced overall assessment of measures despite a potential reduction of trade flows. We show that the relationship between trade, welfare, and NTMs is complex. The optimum NTM is often not zero. An application to shrimp trade illustrates the feasibility of the proposed approach. The illustration shows that the reinforcement of a food safety standard can be socially preferable to the status-quo situation, both domestically and internationally.
\end{abstract}

Keywords: Non-tariff measures, externality, trade, welfare

JEL Classification: F13, D61, D62, Q17

\footnotetext{
* Iowa State University.

\# INRA, UMR Economie Publique INRA-AgroParisTech.

- Corresponding author: OECD, Trade and Agriculture Directorate, 2, rue André Pascal, 75775 Paris, CEDEX 16, France. Phone: +33 1452478 81. Fax: +33 1443061 01. Email: frank.vantongeren@oecd.org.

* Senior authorship is shared. We thank participants at IATRC 2009 Winter Meetings for helpful comments and discussions. The views expressed in this paper are those of the authors and should not be attributed to the OECD or the governments of its member countries.
} 


\section{Introduction}

Regulations in the food and agriculture sectors abound. In many cases they are put in place and enforced by governments in order to address societal interests where unregulated markets are not yielding the desired outcome. In some other cases these measures may be motivated by protectionism or outdated science. Nevertheless, external effects and information asymmetries abound and require intervention, and this paper focuses on those cases.

Many of the regulations address human health issues; others address environmental and animal welfare problems associated with agricultural production. As long as the regulation concerns a non-tradable good (or service) the optimal design of the regulatory measures need not take the interest of foreign parties into account. However, when the product is tradable across national borders, border measures and behind-the border measures are usually taken to assure that the imported varieties meet domestic requirements. Hence, trade flows may be affected by these regulations. Research on non-tariff measures (NTMs) ${ }^{1}$ looks at regulations other than tariffs having an impact on international trade.

With increased international integration in the context of lower tariffs and less stringent quotas, trade is becoming a major potential vector of external effects. Imports can carry invasive species such as pathogens, pests, or weeds, foreign to an economy’s ecology. Furthermore, different trade partners may have different food safety standards and institutional capacity to enforce them. This may lead to imports of agri-food products that do not meet domestic requirements. Imperfect and incomplete monitoring of imports at the border compounds the health or environmental risk (Gossner et al., 2009). In countries with ill-defined property rights, trade may also encourage unsustainable production of some goods

\footnotetext{
1 "NTMs are policy measures, other than ordinary customs tariffs, that can potentially have an economic effect on international trade in goods, changing quantities traded, or prices or both” (MAST, 2008). This definition is too broad to be informative. Here, we further narrow down the definition focusing on the group of measures that indirectly affect price and/or quantity by altering attributes of the goods being sold and their perception by consumers, typically through regulatory measures. We focus on MAST's categories A (technical barriers to trade), B (sanitary and phytosanitary measures), and C (other technical measures).
} 
for the export market, leading to a deterioration concerning global-commons issues (Chichilnisky, 1994). Governments invoke these issues to apply a wide array of NTMs to address real and perceived domestic concerns.

In a few instances, trade is the direct conduit of significant external effects and it may be an option to directly restrict trade. Often many policies tend to be more effective at addressing external effects than others such as blunt trade barriers. Assessing the economic effects of NTMs poses significant challenges as the link between trade, welfare, and policy is tenuous. Many NTMs may restrict trade but can improve welfare in the presence of negative externalities or informational asymmetries. Other measures can expand trade as they enhance demand for a good through better information about the good or by enhancing the good's characteristics (Maertens et al., 2007; Maertens and Swinnen, 2009).

Efficiency costs of NTMs are hence much less evident than the welfare losses associated with tariffs and quantity measures. They do not necessarily embody the economic inefficiencies that are associated with classical trade barriers, unless they discriminate between sources of supply; they may or not be the least trade-restrictive policies available to correct market imperfections and least trade restrictive policies may fail to maximize welfare inclusive of the externality. It is therefore not clear a priori that the trade impacts of the concerned regulations are inefficient, or that removal of associated NTMs that affect trade would achieve efficiency gains relative to the welfare level under existing regulation.

Beyond the type of instrument, the level of intervention is also important in the design of NTMs, such as an optimum maximum residue level or inspection level. In the presence of disease risks, well designed NTMs may allow for some limited amount of trade, while in the absence of measures, such as strict border inspections or restricting imports to products from a specific country or region within a country, no trade will take place at all (Paarlbergh and Lee, 1998; Wilson and Anton, 2006; Pendell et al., 2007 among others). These features of 
NTMs and market imperfections are not well recognized in much of the existing literature, which tends to have a narrow mercantilist focus on foregone trade and trade cost (e.g., Kee et al., 2009). These trade effects have been extensively analyzed with the gravity-equation approach. Many gravity analyses tend to be broad in scope (multi commodity/sector, countries, and policies), which allows for a broad-brush investigation of general hypotheses such as the trade-restricting or expanding effects of NTMs or the impact of harmonization. The gravity equation has also been used to look at specific policy issues such as the European Union (EU) aflatoxin policy (Otsuki et al., 2001). Beyond the well-established trade impeding effects of many NTMs, trade expanding effects also have been identified, often through harmonization and shared standards, in customs unions, and for some goods and policies (Moenius, 1999, 2006; Fontagné et al., 2005; Henry de Frahan and Vancauteren, 2006; and Disdier et al., 2008). A few studies found an absence of trade effects from NTMs in some sectors (Fontagné et al., 2005) and for harmonized measures (Czubala et al., 2009). Effects of NTMs have also been studied with partial and general equilibrium simulation models, usually by parameterizing them as tariff-equivalent in the import demand (or export supply) functions. ${ }^{2}$ Consumer valuation of external effects has been neglected in most of these analyses. The WTO itself tends to focus on effects on trade and producer welfare rather than on effects on consumer welfare, a shortcoming from an economic perspective. Our paper fills that void with a systematic approach to consumer valuation in the economic analysis of NTMs.

The paper develops a unified analytical framework to assess the costs and benefits of NTMs for market stakeholders: domestic consumers, various producers involved in the supply chain, and governments, as well as foreign suppliers, and wherever relevant, foreign consumers and governments. Trade effects are part of the assessment, as NTMs have an

\footnotetext{
${ }^{2}$ See Korinek et al. (2008) for a review of quantitative approaches.
} 
impact on trade as conduit of the externality, but trade effects are not the sole focus. The analytical framework allows comparison of alternative ways to design measures. It discerns their trade and welfare effects. For example, an import ban (or prohibitive standard) to keep the domestic market free of some undesired product characteristic can be compared to allowing trade under clear identification of the foreign product (e.g. through labeling).

An important dimension of the framework is its ability to distinguish those consumers (or producers) that are concerned by the negative or positive externality and product attributes, from those that are not concerned. Concerned consumers put a value to avoiding (consuming) the negative (positive) product characteristic. This valuation is a key variable in the cost-benefit assessment of measures that address failures affecting consumers. Estimating this value empirically is a challenge, but recent advances in consumer economics are promising. On the production side, the value of avoiding a failure is directly related to the value of the production loss that can occur if the failure remains unabated.

We illustrate the approach with an application to shrimp trade and the consumer valuation of information pertaining to food safety characteristics related to antibiotics in shrimps elicited in economic experiments. The cost-benefit framework is essentially a modular partial equilibrium model, with demand and supply relationships, that can be calibrated to empirical data and allowing the calculation of economic welfare effects. The modular set-up renders the approach flexible enough to expand it with side calculations. For example, detailed estimates of costs associated with monitoring and enforcement of measures could easily be added, but are not currently elaborated in this paper.

The welfare-based approach can be used to define optimal non-tariff trade policies. The optimal NTM could well be different from the international standard implied by the sanitary and phytosanitary or technical barriers to trade agreements. The welfare-based NTM could recommend policy stringency exceeding an international standard. The framework is 
also useful for sorting out least-trade restrictive interventions among NTMs considered by policy makers and the potential trade-offs (or lack thereof) between welfare and trade.

The paper is structured as follows: Section 2 discusses the main types of market failures and associated NTM policy instruments. Section 3 presents a modular framework to assess costs and benefits linked to NTMs. Section 4 illustrates the approach with an application to shrimp trade and NTMs using recent findings in consumer valuation. Section 5 concludes.

\section{Market imperfections}

Abstracting from outright protectionism, regulations are designed to address market failures and imperfections. This section discusses major forms of market imperfections and failures which are relevant for NTMs. We consider three different types: 1) those affecting consumers; 2) those affecting producers; and 3) global commons issues, usually related to the conservation of valuable eco-systems.

Many NTMs attempt to remedy external effects. Externalities occur when some agent's utility or production depends on the choices made by other agents, who do not factor these external effects into their decision making. As a consequence, there are costs, or benefits, associated with the externality that fall on some agent but are not reflected in market valuations. It is useful to characterize an externality by its point of impact in order to organize the discussion. When the external cost or benefit arises in consumption it will be referred to as a consumption externality, and similarly for production externalities. As an example, consider harmful chemical residues that arise in production of some food products for which their possible health impact occurs on the consumption side; this type of externality will be referred to as a consumption externality.

Other market imperfections addressed through NTMs relate to the consequences of 
asymmetric information (one partner in a transaction knows more than the other) or imperfect information (not all consequences can be known). These informational problems can also occur on either the consumer or producer side. They can also play a role in the context of monitoring of rules and regulation by governments. Finally, some failures are global in the sense of a global-commons problem for a resource perceived as belonging to the (global) community and requiring collective stewardship. There is a trans-boundary element in the market failure.

\section{Externalities affecting consumers}

This case involves the creation of a negative externality on agents not associated with production or consumption of the good. Consumers are affected by the external effect which is independent from their own consumption basket. If a good releases pollution during either its production or its consumption it may affect other persons who are not at all involved in producing or consuming that good. Consumers' concern about animal welfare is an example. Here some consumers (or rather 'citizens') are concerned about production methods; their welfare is affected regardless of their own decisions to consume or not meat coming from animals produced under certain conditions deemed inhuman. ${ }^{3}$ Consumers could be further disaggregated into consumers in the importing country and those in the exporting country as they may be affected differently.

\section{Asymmetric information on health, safety, or nutritional value}

This type of imperfection is associated with the purchase or the consumption of the good by a final consumer. The consumer derives a benefit from consuming the good but also bears a cost or benefit not exactly known to him via a health impact. Hence, the perceived and true social costs of the good differ. If the consumer is ill-informed about the characteristics of the

\footnotetext{
${ }^{3}$ This case corresponds to damages from the externality that are "separable" from market consumption decisions. The externality affects the representative consumer's welfare but not directly through her market consumption decision. By convention economics treats citizens as consumers whenever citizens are not producers.
} 
good, a situation of asymmetric information prevails. Some attributes, either experience or credence attributes, are unknown or uncertain to the consumer at the time of purchase and may decrease (as in the case of deleterious ingredients) or increase (as in the case of nutritional benefits) the value of the good. There are also attributes that are unsafe to consume and could harm consumers. Recent examples of asymmetric information associated with an undervaluation of health risks are outbreaks of E-coli and salmonella, presence of chemical residues such as melamine residues, unknown to some consumers, in either the importing or the exporting country.

\section{Externalities impacting producers}

External effects arise when the production process of a good is altered by external forces other than prices. Water pollution may impact fishery production, for example. The pollution is generated either by consumption, production, or trade elsewhere or by the ecological environment itself as in the case of soybean rust brought to the United States by hurricanes. The resulting impact is a decrease in production, because of an increase in the cost of production either by loss of efficiency (farm yields fall) or by trying to abate the external effects (fungicide applications to eliminate some fungus). These occurrences may be nonrival (a whole region is hit by a food and mouth disease outbreak) or private (a single livestock producer hit by contamination of feed).

\section{Asymmetric information in production}

Producers, like consumers, may also suffer from asymmetric information and purchase inputs with unsafe attributes (e.g., a seed-borne disease could lower profits).

\section{Global common issues}

Global commons or common-pool resources refer to resources perceived as belonging to the (global) community and requiring collective stewardship. They are open access resources, for which property rights are not well defined or not defined at all. Examples of such global 
commons problems include unsustainable resource use in forest products, depletion of fish stocks through over-fishing, and agricultural production with negative impacts on biodiversity. Consumers do not need to consume a specific good themselves to suffer the externality. However, consumers may derive benefits from consuming products certified as respecting the commons. Eco-labels and fair trade are well known examples of measures providing perceived benefits to consumers with global-commons concerns.

Although the analytical treatment of global commons cases will often be closely related to the treatment of externalities affecting consumers, it is worth distinguishing the former as an increasing number of trade frictions between high-income and low-income economies are based on global commons issues and as interest in sustainable practices expands. Trade is often central: a good is imported from a source characterized by globalcommons issues or unsustainable practices. A NTM in the importing country may attempt to alleviate the global-commons problem in the sourcing country.

\section{Imperfect monitoring and other government failures}

In practice, the implementation of existing regulatory policies can only be imperfectly monitored and incompletely enforced. In this sense governments are failing by not doing enough, i.e., a failure by omission. The limited institutional capacity to monitor and enforce regulations sometimes calls for additional interventions, or may necessitate policies that would not be welfare-optimal if monitoring were perfect. Mitigating the institutional deficiencies can have strong trade implications and bring costly policies. A failure to detect and contain food and mouth disease or bovine spongiform encephalopathy early can induce a collapse of trade if partners are closing borders as an emergency measure. If institutional capacity for border inspection is limited, a country might chose to designate just one port of entry for imports of certain food products, and this measure can lead to an additional trade cost. Other policy responses may be more cooperative when they can be planned, especially 
in the North-South context. For example, coordination of policies such as certification of South exporters by importing countries in the North providing the additional capacity missing in the exporting country (e.g. the EU assisting Latin American meat packers to meet EU food sanitary and phytosanitary standards).

All these market imperfections can be addressed through a wide range of policies, but this paper concentrates on those policies that have a potential impact on international trade flows, singling out NTMs.

\section{Cost-benefit framework: a modular approach}

This section presents a simplified framework that allows the assessment of economic effects of NTMs designed to address different types of market failures and market imperfections mentioned above. The framework is particularly tailored to our empirical application presented in section 4 . On the consumer side, the approach rests on insights from modern empirical consumer economics and on the producer side it incorporates insights from epidemiological studies.

The framework is modular, essentially a partial equilibrium model. New elements with detailed side calculations can be attached or removed from the main structure without the necessity to alter the general logic of the approach. The theoretical framework is designed to be applied with empirical data to facilitate a quantitative cost-benefit analysis. Not each and every potential effect is discussed here, as the framework may be easily extended in many directions to analyze particular trade problems. One element not elaborated here, but which can be important in practice, concerns costs related to administration, monitoring, and enforcement.

The framework comprises "modules" for calculation of costs and benefits affecting (a) domestic consumers, (b) domestic producers, (c) domestic government, and (d) foreign 
producers. For simplicity, foreign consumers and governments are not included here. In addition, the different actors in the supply chain (farmers, processors, retailers etc.) are collapsed into a single production stage representing supply. These abstractions influence results in many cases but are maintained here to preserve clarity in exposition. The exposition introduces a minimum of technical detail. Because of a lack of space, we only focus on market failures affecting consumers. ${ }^{4}$ The market good being analyzed here is assumed to be homogenous and presents a specific characteristic.

We assume that, without regulation, producers offer a good with a specific characteristic (an environmental or safety risk or a specific process of production) that domestic consumers do not want. The regulation therefore protects domestic consumers regarding the specific characteristic conveyed by products.

We focus on a regulation corresponding to a safety standard ${ }^{5}$ that fully eliminates the characteristic such as a ban on some antibiotics eliminating antibiotic residues in food. For food safety, the standard is the most likely instrument compared to a voluntary label signaling higher level of safety than the level offered by regular products (see van Tongeren et al., 2009 for a case with a label). The model discussed below assumes that foreign and domestic producers have different technologies for food safety, which means they are not similarly impacted by the enforcement of a standard (for heterogeneous producers also see Marette and Beghin, 2010). In the baseline, the domestic firms are assumed to have implemented the standard, so that additional compliance costs fall only on foreign firms. However, the analytical simplification maintained here allows a sharper focus on the implications of regulatory heterogeneity between countries, reflecting differences in what is considered

\footnotetext{
${ }^{4}$ Production-based failures, such as animal or plant disease outbreaks, can also be conceptualized as a negative shock on supply, inducing a shift or a pivot of the marginal cost curve (see Orden and Romano, 1996; Wilson and Anton, 2006; Peterson and Orden, 2008).

5 The term 'standard' is used here to denote mandatory product and process requirements imposed by governments. The trade literature often reserves this term to private voluntary arrangements, while it uses the term 'regulation' to refer to government policies.
} 
appropriate product characteristics. This assumption is particularly valid for the application to shrimp trade which is elaborated later.

\section{Supply side}

A perfectly competitive industry with price taking firms is assumed for both domestic and foreign supplies. We abstract from the export or re-export from the domestic country, implying that imports and domestic production are only purchased by domestic consumers.

There are $M_{O}$ domestic firms and $M_{F}$ foreign firms. Firms' cost functions are quadratic in output, and they are choosing output to maximize profits:

$$
\pi_{s j}=p q_{s j}-f_{s} q_{s j}-1 / 2 c_{s} q_{s j}^{2} \text { for } j=\left\{1, \ldots, M_{s}\right\} ; s=\{O, F\},
$$

where $c_{s}, f_{s}$ are the variable cost parameter. ${ }^{6}$ Profit maximization yields individual firm supply functions which can be added up to yield industry supply $Q .^{7}$ The firms' inverse supplies are expressed as

$$
\begin{aligned}
& p_{O}^{S}\left(Q_{O}\right)=c_{O} Q_{O} / M_{O}+f_{O} \\
& p_{F}^{S}\left(Q_{F}\right)=c_{F} Q_{F} / M_{F}+f_{F} .
\end{aligned}
$$

The total inverse supply defined by the sum of foreign and domestic supply is

$$
p_{O+F}^{S}\left(Q_{O}\right)=\frac{c_{O} c_{F} Q_{O}+f_{F} c_{O}+f_{O} c_{F}}{c_{O} M_{F}+c_{F} M_{O}}
$$

For the rest of the analysis we assume that $c_{O}>c_{F}$ and $f_{O}>f_{F}$; domestic producers incur higher marginal cost than foreign producers. This reflects a situation where domestic production incurs a costly effort to eliminate the specific characteristic (an environmental/safety risk or a specific process of production) that some domestic consumers

\footnotetext{
${ }^{6}$ We could also extend the analysis with a sunk cost $K_{s}$ linked to the firm's market entry and compliance with regulations.

${ }^{7}$ Individual supply functions are only defined for prices exceeding average costs, because otherwise firms would obviously cease production.
} 
do not want, while foreign producers do not eliminate the characteristic and do have to bear these additional costs. ${ }^{8}$

If the safety standard is imposed, the inverse supply of foreign producer can be represented as a multiple of the original supply: $\bar{p}_{F}^{S}\left(Q_{F}\right)=\lambda\left(c_{F} Q_{F} / M_{F}+f_{F}\right)$ with $\lambda>1$. Recall that only foreign producers are impacted by the adoption or the reinforcement of the safety standard via a variable cost increase; domestic producers are not impacted since they already offer food products without the specific characteristic. From some empirical parameterization of the model, it is possible to know the relative change $\gamma$ in the inverse supply curve, namely the price increase per unit relative to the supply linked to the baseline scenario. Thus the relative change in the supply curve at the equilibrium is defined by $\gamma=\left[\bar{p}_{F}^{S}\left(Q_{F}\right)-p_{F}^{S}\left(Q_{F}\right)\right] / p_{F}^{S}\left(Q_{F}\right)=\lambda-1$. Thus the parameter of the supply $\bar{p}_{F}^{S}\left(Q_{F}\right)$ after the standard implementation is equal to $\lambda=1+\gamma$.

\section{Demand side}

The characterization of preferences largely follows Polinsky and Rogerson (1983). For simplification purposes all consumers are concerned. Consumers unanimously prefer safe food. Demands are derived from quadratic preferences. Demand of each consumer $i=\{1, \ldots, N\}$ in the importing country is derived from a quasi-linear utility function that consists of the quadratic preference for the market good of interest and an additive numéraire:

$$
U_{i}\left(q_{i}, w_{i}\right)=a q_{i}-\bar{b} q_{i}^{2} / 2-I(1-S) r_{i}\left(Q_{F} / Q\right) q_{i}+w_{i}
$$

where the term $a q_{i}-\bar{b} q_{i}^{2} / 2$ is the immediate satisfaction of consumer $i$ from consuming a quantity $q_{i}$ of the good and $w_{i}$ is the numéraire good consumed by $i$. For simplicity $a, \bar{b}$ are the same for the $N$ consumers. The consumer cannot distinguish the two goods (foreign

\footnotetext{
${ }^{8}$ Measuring cost of regulatory compliance for firms is far from straightforward. Various methods have been used: firm-level surveys (e.g. Wilson and Otsuki, 2004), price comparisons (Ferrantino, 2006; Yue et al., 2006), cost accounting (e.g. Grothe et al., 2000), econometric estimations (Antle, 2000; Maskus et al., 2005).
} 
versus domestic).

The binary variable $S$ indicates the safety standard policy. Under the absence of standard with $S=0$, the per-unit damage $r_{i}$ is linked to the foreign product purchased by the consumer. Only a fraction $\left(Q_{F} / Q\right)$, with $Q=Q_{F}+Q_{O}$, of the good on the market has the specific characteristic. The perceived damage associated with the consumption of the good with the specific characteristic is denoted $r_{i}\left(Q_{F} / Q\right) q_{i}$.

The effects of information are captured by the term $-I r_{i} q_{i}\left(Q_{F} / Q\right)$. The binary parameter $I$ represents the knowledge regarding the specific characteristic brought by the good. If consumers are unaware of the specific characteristic or if there is an unaccounted externality linked to the specific characteristic, then $I=0$. Conversely, $I=1$ means that consumers are aware of the specific characteristic and internalize the externality and reduce their consumption. Creating this awareness can be part of food safety policy packages.

For the rest of the analysis, we consider both situations ( $I=0$ and $I=1)$. First with $I=0$, the non-internalized damage should be accounted for in the welfare calculations, but does not feedback in the demand. Second with $I=1$, consumers internalize the damage and demand is reduced. When the safety standard is implemented $(S=1)$, the damage completely disappears, which makes both alternative situations of consumer awareness ( $I=0$ and $I=1)$ equivalent.

The maximization of the utility function under a budget constraint yields a demand function for each consumer. Aggregate demand for the good is obtained by summing individual demand functions over all $N$ consumers. The associated damage per unit consumed is equal to $r\left(Q_{F} / Q\right)$ for the $N$ consumers. With $b=\bar{b} / N$, the overall (inverse) demand function for all consumers is $p(Q, I, r)=a-b Q-I(1-S) r\left(Q_{F} / Q\right)$.

Parameterization of $r$ is crucial to the empirical assessment. Survey and lab experiment providing information on consumer willingness-to-pay (WTP) for a good can be 
used here. More precisely, $r$ is defined with the relative change in the average consumer WTP. The value of the relative change is computed as follows: $\delta=\left[E\left(W T P_{\text {Info }}\right)-E\left(W T P_{\text {NoInfo }}\right)\right] / E\left(W T P_{\text {NoInfo }}\right)$ by using the average WTP before and after the revelation of information to the consumers on the specific characteristic that the good may present. Thus, using the relative price variation linked to the damage internalization is equal to the inverse demand shift defined by $[p(Q, 1, r)-p(Q, 0, r)] / p(Q, 0, r)=\delta$, which leads to $r=\delta \times p(Q, 0, r)$ (see Marette et al., 2008 for details). Under the absence of the standard $(S=0)$, this value is internalized in the demand when consumers are aware $(I=1)$ or used for the calculation of the cost of ignorance when consumers are unaware $(I=0)$.

\section{Equilibrium}

Equilibrium is first presented for the situation where consumers are unaware of the damage when no regulation is implemented. Figure 1 shows domestic demand $(D)$, foreign supply $\left(S_{F}\right)$ and total supply $\left(S_{O}+S_{F}\right)$ (the domestic supply $S_{O}$ is omitted for clarity). The price, $p$, is located on the vertical axis and the quantity, $Q$, is shown along the horizontal axis.

Free trade without regulation leads to an equilibrium $E$. The equilibrium price $p^{E}$ clears the market by equalizing demand and supply with an overall equilibrium quantity $Q^{E}$. $Q_{F}^{E}$ is foreign output and $Q^{E}-Q_{F}^{E}$ is domestic output. The profits correspond to area $O x v p^{E}$ for foreign producers and area $x v E z$ for domestic producers. The usual surplus of domestic consumers corresponds to area $p^{E} a E$. The foreign products with the characteristic leading to the damage do not influence the demand since $I=0$. The corresponding cost of ignorance for domestic consumers is accounted for in the welfare calculations and is equal to $r Q_{F}^{E}$ represented by the area $0(-r) t Q_{F}^{E}$. Domestic welfare is the sum of domestic producers' profits and consumer surplus minus the cost of ignorance. International welfare is the sum of 
domestic welfare and foreign producers' profits. $^{9}$

\section{[INSERT FIGURE 1]}

When a safety standard is adopted or enforced on foreign suppliers, the market allocation is modified as represented in figure 1 with the bold curves $\bar{S}_{F}, S_{D}+\bar{S}_{F}$ and the equilibrium point $H$. Assuming that the stringent regulation increases cost of production of the foreign producers, supply is reduced relative to the initial equilibrium point $v$ in figure 1 . In other words, from the initial equilibrium quantity, the overall marginal costs increase by $2 p^{E}$ for foreign producers. The supply shifts increases the equilibrium price to $p^{H}$, which reduces consumer surplus: $p^{H} a H<p^{E} a E$. For domestic consumers, the initial damage (represented by the area $\left.0(-r) t Q_{F}^{E}\right)$ ) fully disappears once the standard is enforced. The overall effect of a stricter standard is ambiguous for consumers since it depends on the comparison between the surplus reduction and disappearance of the damage. The effect is also ambiguous for foreign producers since their production decreases for any given price, while the equilibrium price increases. The domestic producers have a higher profit $w c H u>$ $x v E z$, since their supply curve did not change, while the price is higher. The overall comparison for different agents will be elicited in the next section, which introduces a simple application based on the mechanism depicted in figure 1.

We now turn to the case where consumers are (or become) aware of the damage and internalize it. In this case, the baseline scenario (without standard) changes from the initial equilibrium $E$ in figure 1 to initial equilibrium $K$ in figure 2. Internalizing the damage decreases demand and baseline profits and the cost of ignorance disappears. The equilibrium price $p^{K}$ internalizes the damage in the demand. The enforcement of the standard in this case helps increase the demand, which leads to the new equilibrium $H$ still in figure 2. Changes in

\footnotetext{
${ }^{9}$ Full analytical expressions for equilibrium values as well as for all the components of welfare can be provided upon request.
} 
profits and surplus stemming from the standard are different from those in figure 1. Foreign producers can gain from the standard as the equilibrium price increases when the equilibrium shifts from $K$ to $H$. With aware consumers in the importing country it may be in the interest of foreign suppliers to have stricter standards enforced.

\section{[INSERT FIGURE 2]}

\section{Application with shrimp quality and trade frictions}

In this illustration, we simulate the impact of a safety standard eliminating the use of antibiotics in shrimp aquaculture, a widespread problem in many operations. Production and trade of shrimp products have seen a significant rise over the last decade globally and with dominant trade flows from emerging developing countries to OECD countries, especially the EU and the United States (Roheim, 2004). However, this expansion occurred at some health costs because the quality of seafood imports has been variable. The sanitary quality of seafood production in some developing countries has been subpart through the use of additive substances harmful to humans. To prevent and treat bacterial infections and other pathogens, shrimp producers use a range of pesticides, harmful drugs and antibiotics, which are toxic to human health. The illustration focuses on the EU-15. We measure the impact of a new stringent standard that could be adopted by the European Authorities and aiming at eliminating all antibiotic residues in shrimps. ${ }^{10}$ Testing technology has also evolved and the ability to detect ever smaller residues has been improved (Debaere, 2010). Note that the use of these antibiotics has been already banned inside the EU for many years. Therefore and consistent with the assumptions in our presented framework, the standard adopted by the European Authorities only affects non-European producers.

With the initial situation preceding an enforcement of the regulation on foreign

\footnotetext{
${ }^{10}$ This standard could follow the organic process developed by Madagascar (Hervieu, 2009).
} 
suppliers, parameters of the model are calibrated in such a way as to replicate market prices and quantities for the year 2006 in the EU-15 (corresponding to the equilibrium $E$ in figures 1 and 2). With the baseline scenario before the enforcement of the standard it is assumed that only foreign products use antibiotics. With the observed quantity $\hat{Q}_{E}$ sold over a period, the average price $\hat{p}_{E}$ observed over the period, and the direct price elasticity $\hat{\varepsilon}$ obtained from econometric estimates, the calibration leads to estimated values equal to $1 / \tilde{b}=-\hat{\varepsilon} \hat{Q}_{E} / \hat{p}_{E}$, $\tilde{a}=\tilde{b} \hat{Q}_{E}+\hat{p}_{E}$ for a demand $Q=(a-p) / b$; the same method can be used for the supply side. Table 1 details the parameters used for calibrating the baseline scenario with $I=0$, namely when consumers are not aware of the antibiotic problem.

\section{[INSERT TABLE 1]}

The value of the per-unit damage associated with foreign shrimp, $r$, defined in figure 1 , is determined by using results from a consumer choice experiment. This experiment was conducted in Paris, France, in multiple one-hour sessions in December 2009. The sample included 160 participants randomly selected based on the quota method. A multiple price list was used for eliciting consumers' WTP for a $100 \mathrm{~g}$ plastic package of farmed, midsize, shelled, cooked, and refrigerated shrimps. Cooked and refrigerated shrimps are the most common form of shrimp consumption in France. Participants were asked to choose whether or not they would buy the product for prices varying from $€ 0.25$ to $€ 4$ with a 25-cent interval between possible choices (Disdier and Marette, 2010a). Here, we use two of the WTPs elicited during this experiment: A first one before the revelation of any information and a second one after the revelation of information on food safety for shrimps produced in nonEuropean countries. These two WTP estimates allow measuring the marginal impact of information.

Information about the willingness to pay for increased food safety was revealed 
through responses to the following message:

"Many bacteriological infections affect shrimp breeding pools. The bad production conditions (bad water quality for example) favor the growth of bacteria. To fight against these bacteria, shrimp producers in some developing countries use antibiotics and other chemical products that are toxic to human health and therefore forbidden in almost all countries. Given the difficulties and the cost of inspection of products, it is likely that some shrimps sold in France were treated with these antibiotics and chemical products toxic to human health.”

The average WTP expressed by participants in the experiment, before the information revelation, is equal to $€ 2.14$ for tropical (foreign) shrimp, while the average WTP after the revelation is equal to $€ 1.13$. The relative variation of the WTP is therefore equal to (1.132.14)/2.14= -0.47 . This value is applied to the per-unit damage relative to the equilibrium price. Applying the price $p^{E}$ used for the initial calibration to the relative variation, the perunit damage is equal to $r=0.47 \times p^{E}$. Using this value, the cost of ignorance is $r_{i} Q_{F}^{E}$ when $I=0$ (see figure 1) and the internalized per-unit damage is $r_{i} Q_{F}^{K} / Q^{K}$ when $I=1$ (see figure 2).

Eventually, the enforcement of the safety standard by the EU Authorities leads shrimp producers from developing countries to avoid antibiotics. The impact of avoiding antibiotics on the supply is determined as follows. Based on an analysis of organic shrimps in Madagascar, Hervieu (2009) notes that the switch from non-organic to organic shrimps increases the variable cost of production (farm price) from $5 € / \mathrm{kg}$ to $8 € / \mathrm{kg}$. Organic production does not use antibiotics. Thus, we apply this change in variable unit cost to our model. The relative variation of the supply is equal to $\gamma=(8-5) / 5=0.6$ and is applied to the foreign supply curves presented in figures 1 and 2. Recall from figures 1 and 2 that only foreign products lead to the damage for consumers and only foreign producers are impacted 
by the safety standard getting rid of the damage.

Table 2 presents the variation in domestic consumers' surplus (including the cost of ignorance linked to the damage for unaware consumers), the variation in domestic producers’ profits, the variation in foreign producers' profits, and the relative variation in international welfare, which includes both domestic welfare and foreign producers' profits following the enforcement of the safety standard. All of these measures refer to 2006. The first column corresponds to the market adjustment when consumers are unaware of the damage under the absence of standard as in figure 1 . The second column corresponds to the market adjustment when consumers are aware of the damage $(I=1)$ that would occur if the standard were absent (figure 1).

\section{[INSERT TABLE 2]}

The results of table 2 show that, when the standard is implemented, foreign producers decrease their output and domestic producers increase their output (by taking the difference between the first line and the second line for each column), since domestic producers enjoy a better price without suffering the cost increase. Domestic consumers and domestic producers would benefit from a standard eliminating dangerous antibiotics. The variation in consumers' surplus (including the cost of ignorance when $I=0$ ) is higher when consumers are initially unaware of the damage than when they are aware of the damage, since the cost of ignorance is eliminated by the safety standard with unaware consumers. The variation in consumers' surplus is relatively low with aware consumers since the positive effect linked to the disappearance of the internalized damage is partially offset by the negative effect linked to the price increase.

Foreign producers suffer from the standard only with unaware consumers $(I=0)$ as described in figure 1, while they benefit from the standard if consumers are fully aware of the 
antibiotics problem and of the solution in the form of a strict enforcement of the production standard at the border $(I=1)$; in this case the increase in consumer demand leads to higher prices and profits even for foreign producers. With $I=0$, international welfare increases, but there are pronounced distribution effects as foreign producers lose profits. With $I=1$, the NTM should not be controversial since the safety standard benefits all foreign and domestic agents. For both cases ( $I=0$ and $I=1$ ), the international welfare linked to the regulation increases, while the imports decrease (see the second line of table 2). It means that considering only trade volumes or values can be insufficient for characterizing an NTM.

This application shows that the enforcement of a food safety standard can be socially preferable to the status-quo situation, both domestically and internationally. The size of the estimated damage that is avoided by enforcing stricter standards at the border is obviously crucial to this result. A second driver is the estimated cost of switching to alternative production methods, in this case antibiotics-free shrimp production. Alternatives must be available, and the additional cost must be low enough to provide incentives to foreign suppliers to switch production methods. Finally, the most beneficial policy package combines enforcement of the standard at the border with generating consumer awareness of the food safety issue.

It should be kept in mind, though, that the numerical magnitudes of the estimated welfare effects presented here depend crucially on the underlying functional forms (linear demand and supply functions) and on the quality of data and parameters.

Many extensions to the relatively simple illustration discussed here can be considered. For instance, an export demand for the EU could be estimated and considered since the EU is a relatively large actor. Gravity results linked to the previous regulation enforcement could be also considered (Disdier and Marette, 2010b). A scenario with a label signaling the origin and a high level of safety could be studied (Bureau et al., 1998). 
Non-prohibitive standards where both domestic and foreign firms make costly efforts to comply and consumers are to some extent able to identify the degree of compliance can easily be accommodated. Other extensions include entry and exit of firms in the face of fixed (through additional investments) and variable (through additional activities) compliance cost, If compliance with standards and regulations implies large investments that are sunk once undertaken, economies of scale become an important characteristic of the industry structure (Rau and van Tongeren, 2007, 2009; Maertens and Swinnen, 2009). Sunk investments do not figure in the firms' optimal pricing decisions and have more indirect effects on market prices through entry and exit of firms. Only firms that are sufficiently productive to "jump the hurdle” of fixed market entry costs will be able to export.

\section{Concluding remarks}

Efficiency implications of NTMs are much less evident than the welfare losses associated with tariffs and quota. NTMs do not necessarily embody the economic inefficiencies that are associated with classical trade barriers, unless they discriminate between sources of supply, and they may be the least trade-restricting policies available in the face of market imperfections. It is therefore not clear a priori that the trade impacts of regulations are inefficient, or that removal of associated NTMs that affect trade would achieve efficiency gains that would exceed the losses from weaker regulation.

The increasing prevalence of NTMs is a permanent reality of trade in agri-food. A systematic assessment of their effects, across countries and products, is much warranted, in particular in view of the rising occurrence of trade frictions about food safety and food quality (Josling et al., 2004; Disdier and van Tongeren, 2010).

This paper contributes to a systematic analysis of economic costs and benefits of NTMs, focusing on the often neglected aspect of consumer benefits from regulations that aim 
at addressing market failures in the food sector. The proposed methodology is operational for comparing alternative policy choices like standards, border inspections policy and labeling in an international context. The methodology contributes to a more comprehensive welfare analysis of NTMs than that offered by looking at trade effects alone.

The illustrative application to shrimp trade in the face of EU regulations aiming at eliminating consumption of shrimps that contain antibiotics shows that enforcement of such a production standard can be welfare enhancing, both domestically and internationally. The benefits are more widely shared between domestic and foreign players if domestic consumers are made fully aware of the particular health problem and the solutions in the form of a strictly imposed production standard. The clear policy message is that a well designed policy package combines enforcement of the standard at the border with generating consumer awareness of the food safety issue.

The proposed comparative approach to NTMs allows for the identification of alternative ways to address a given regulatory problem. By systematically enumerating costs and benefits for all the different economic actors involved, an evidence-based approach can be followed that yields a solid basis for mutual exchange and identification of least-cost solutions. 


\section{References}

Antle, J. (2000), “No Such Thing as Free Safe Lunch: the Cost of Food Safety Regulation in the Meat Industry,” American Journal of Agricultural Economics, 82(2): 310-322.

Asche, F., and T. Bjørndal (2001), "Demand Elasticities for Fish and Seafood: A Review,” Unpublished, Centre for Fisheries Economics, Norwegian School of Economics and Business Administration.

Bureau J. C., S. Marette and A. Schiavina (1998), "Non-Tariff Trade Barriers and Consumers' Information: The Case of EU-US Trade Dispute on Beef.” European Review of Agricultural Economics, 25(4): 437-462.

Chichilnisky, G. (1994), "North-South Trade and the Global Environment,” American Economic Review, 84(4): 851-874.

Czubala, W., B. Shepherd, and J.S. Wilson (2009), "Help or Hindrance? The Impact of Harmonised Standards on African Exports,” Journal of African Economies, 18(5): 711744.

Debaere, P. (2010), “Small Fish - Big Issues. The Impact of Trade Policy on the Global Shrimp Market,” World Trade Review, 9(2): 353-374.

Dey, M.M., U-P. Rodriguez, R.M. Briones, C.O. Li, M.S. Haque, L. Li, P. Kumar, S. Koeshendrajana, T.S. Yew, A. Senaratne, A. Nissapa, N.T. Khiem, and M. Ahmed (2004), “Disaggregated Projections on Supply, Demand, and Trade for Developing Asia: Preliminary Results from the Asiafish Model,” Paper presented at IIFET Meeting, Tokyo, 21-30 July.

Disdier, A-C., L. Fontagné, and M. Mimouni (2008), “The Impact of Regulations on Agricultural Trade: Evidence from SPS and TBT Agreements,” American Journal of Agricultural Economics, 90(2): 336-350.

Disdier, A-C. and S. Marette (2010a), "How do consumers in developed countries value the 
environment and workers’ social rights in developing countries?,” INRA, Manuscript.

Disdier, A-C. and S. Marette (2010b), “The Combination of Gravity and Welfare Approaches for Evaluating Non-Tariff Measures,” American Journal of Agricultural Economics, 92(3): 713-726.

Disdier, A-C, and F. van Tongeren (2010), “Non-Tariff Measures in Agri-Food Trade: What Do the Data Tell Us? Evidence from a Cluster Analysis on OECD Imports,” Applied Economic Perspectives and Policy, 32(3): 436-455.

Ferrantino, M. (2006), "Quantifying the Trade and Economic Effects of Non-Tariff Measures,” OECD Trade Policy Working Papers, No. 28, OECD Publishing.

Fontagné, L., M. Mimouni and J-M. Pasteels (2005), "Estimating the Impact of Environmental SPS and TBT on International Trade,” Integration and Trade Journal, 22: 7-37.

Gossner, C.M., J. Schlundt, P. Ben Embarek, S. Hird, D. Lo-Fo-Wong, J.J. Beltran, K.N. Teoh, and A. Tritscher (2009), “The Melamine Incident: Implications for International Food and Feed Safety,” Environmental Health Perspectives, 117(12): 1803-1808.

Grothe, U., C. Deblitz, and S. Stegmann (2000), “Total Costs and Environmental Standards for Selected Agricultural Products in Brazil, Germany and Indonesia: the Impact on International Competition,” Quarterly Journal of International Agriculture, 19(3): 299318.

Henry de Frahan, B., and M. Vancauteren (2006), "Harmonization of Food Regulations and Trade in the Single Market: Evidence from Disaggregated Data,” European Review of Agricultural Economics, 33(3): 337-360.

Hervieu, S. (2009), “A Madagascar, la Seule Crevette d’Elevage Bio du Monde,” Le Monde, April 1 ${ }^{\text {st }}$, p.4.

Josling, T., D. Roberts, and D. Orden (2004), Food Regulation and Trade: Toward a Safe 
and Open Global System, Institute for International Economics, Washington DC.

Kee, H.L., A. Nicita, and M. Olarreaga (2009), “Estimating Trade Restrictiveness Indices,” The Economic Journal, 119: 172-199.

Korinek, J., M. Melatos, and M.L. Rau (2008), “A Review of Methods for Quantifying the Trade Effects of Standards in the Agri-Food Sector,” OECD Trade Policy Working Papers, No. 79, OECD Publishing.

Maertens, M., L. Dries, F.A. Dedehouanou, and J.F.M. Swinnen (2007), “High-Value Supply Chains, Food Standards and Rural Households in Developing Countries,” in J.F.M. Swinnen (ed.), Global Supply Chains, Standards and the Poor, Cabi Publishing, Wallingford, pp. 159-172.

Maertens, M. and J.F.M. Swinnen (2009), “Trade, Standards, and Poverty: Evidence from Senegal,” World Development, 37(1): 161-178.

Marette, S. and J.C. Beghin (2010), “Are Standards Always Protectionist?” Review of International Economics, 18(1): 179-192.

Marette S., J. Roosen, S. Blanchemanche, P. Verger (2008), The Choice of Fish Species: An Experiment Measuring the Impact of Risk and Benefit Information. Journal of Agricultural and Resource Economics, 33: 1-18.

Maskus, K., T. Otsuki, and J.S. Wilson (2005), "The costs of compliance with product standards for firms in developing countries: an econometric study,” World Bank Working Paper, No. 3590, Washington DC.

MAST (Multi-Agency Support Team) (2008), "First Progress Report to the Group of Eminent Persons on Non-tariff Barriers (June 2008),” UNCTAD, Manuscript, Geneva.

Moenius, J. (1999), "Information versus Product Adaptation: The role of Standards in Trade,” University of California Working paper, No. 11/2499, San Diego.

Moenius, J. (2006), “The Good, the Bad and the Ambiguous: Standards and Trade in 
Agricultural Products,” University of Redlands, Manuscript.

Orden, D., and E. Romano (1996), “The Avocado Dispute and Other Technical Barriers to Agricultural Trade Under NAFTA," invited paper presented at the conference "NAFTA and Agriculture: Is the Experiment Working,” San Antonio (TX).

Otsuki, T., J.S. Wilson, and M. Sewadeh (2001), "What Price Precaution? European Harmonisation of Aflatoxin Regulations and African Groundnut Exports,” European Review of Agricultural Economics, 28(3): 263-283.

Paarlberg, P.L. and J.G. Lee (1998), “Import Restrictions in the Presence of a Health Risk: an Illustration using FMD,” American Journal of Agricultural Economics, 80(1): 175-183.

Pendell, D.L., J. Leatherman, T.C. Schroeder, and G.S. Alward (2007), “The Economic Impacts of a Foot-And-Mouth Disease Outbreak: A Regional Analysis,” Journal of Agricultural and Applied Economics, 39: 19-33.

Peterson, E.B. and D. Orden (2008), “Avocado Pests and Avocado Trade,” American Journal of Agricultural Economics, 90(2): 321-335.

Polinsky, A.M. and W. Rogerson (1983), "Products Liability and Consumer Misperceptions and Market Power,” The Bell Journal of Economics, 14(2): 581-589.

Rau, M.L, and F. van Tongeren (2007), “Modeling differentiated quality standards in the agri-food sector: the case of meat trade in the enlarged EU,” Agricultural Economics, 37(2-3): 305-315.

Rau, M.L. and F. van Tongeren (2009), "Heterogeneous firms and homogenizing standards in agri-food trade: the Polish meat case,” European Review of Agricultural Economics, 36(4): 479-505.

Roheim, C. (2004), “Trade Liberalization in Fish Products: Impacts on Sustainability of International Markets and Fish Resources,” in A. Aksoy and J. Beghin (eds.), Global Agricultural Trade and Developing Countries, The World Bank, Washington, DC, pp. 
275-295.

United Nations Food and Agriculture Organization (2009), FishStat Plus - Universal Software for Fishery Statistical Time Series, Rome.

van Tongeren, F., J. Beghin, and S. Marette (2009), “A Cost-Benefit framework for the Assessment of Non-Tariff Measures in Agro-Food Trade,” OECD Food, Agriculture and Fisheries Working Papers, No. 21, OECD Publishing.

Wilson, J.S. and T. Otsuki (2004), "Standards and Technical Regulations and Firms in Developing Countries: New Evidence from A World Bank Technical Barriers to Trade Survey,” World Bank, Manuscript.

Wilson, N.L. and J. Anton (2006), “Combining Risk Assessment and Economics in Managing a Sanitary-Phytosanitary Risk," American Journal of Agricultural Economics, 88(1): 194-202.

Yue, C., J.C. Beghin, and H.H. Jenson (2006), “Tariff Equivalent of Technical Barriers to Trade with Imperfect Substitution and Trade Costs,” American Journal of Agricultural Economics, 88(4): 947-960. 
Table 1. Values of parameters for the calibrated model of shrimps in 2006

\begin{tabular}{lc}
\hline Variable & European Union (EU-15) \\
\hline Domestic production sold on the domestic & 49,970 \\
market (tons) & \\
Imports sold on the domestic market (tons) & 473,196 \\
Consumption in 2006 (tons) & 523,166 \\
Price per kg in 2006 (US \$) & 6.29 \\
Own-price elasticity of demand $^{\mathrm{b}}$ & -0.67 \\
Own-price elasticity of supply (domestic $^{\text {and foreign) }}$ & 0.97 \\
\hline
\end{tabular}

Note: quantities and prices in 2006 come from United Nations Food and Agriculture Organization (2009).

a: The domestic price was estimated by dividing the average value of imports by the quantity of imports and exports in the EU (United Nations Food and Agriculture Organization, 2009).

${ }^{\mathrm{b}}$ : Asche and Bjørndal (2001) for crustaceans in the European Union.

c: Dey et al. (2004) for the aquaculture of shrimps by taking the average of own-price elasticities of demand over the top 5 world producers of shrimps in table 3 (p. 5). 
Table 2. Welfare changes for the year 2006 linked to the safety standard enforced at the border

\begin{tabular}{lcc}
\hline European Union - 15 & Unaware & Aware \\
& Consumers $(I=0)$ & Consumers $(I=1)$ \\
\hline Change in quantity consumed (tons) & $-87,966$ & 166 \\
& $(-16.8 \%)$ & $(0.03 \%)$ \\
Change in imports (tons) & $-100,131$ & $-20,415$ \\
& $(-21.1 \%)$ & $(-5.1 \%)$ \\
Price change (US\$ per kg) & 1.57 & 2.67 \\
& $(25 \%)$ & $(51 \%)$ \\
Change in domestic consumers surplus & $-756,408,719$ & $1,303,265$ \\
(without the cost of ignorance) (US\$) & $(-71.5 \%)$ & $(0.07 \%)$ \\
Change in cost of ignorance with unaware & $1,398,911,824$ & \\
consumers only (I=0) & $(+100 \%)$ & \\
Change in domestic producers profits & $88,480,594$ & $138,469,958$ \\
(US\$) & $(54 \%)$ & $(123.6 \%)$ \\
Change in domestic welfare (US\$) & $730,983,699$ & $139,773,223$ \\
Change in foreign exporters profits (US\$) & $(59 \%)$ & $(7.7 \%)$ \\
Change in international welfare (US\$) & $-8,430,689$ & $464,948,019$ \\
& $(-0.5 \%)$ & $(43.8 \%)$ \\
& $722,553,010$ & $604,721,242$ \\
\hline
\end{tabular}

Note: relative changes (\%) compared to the baseline scenario in parentheses. 


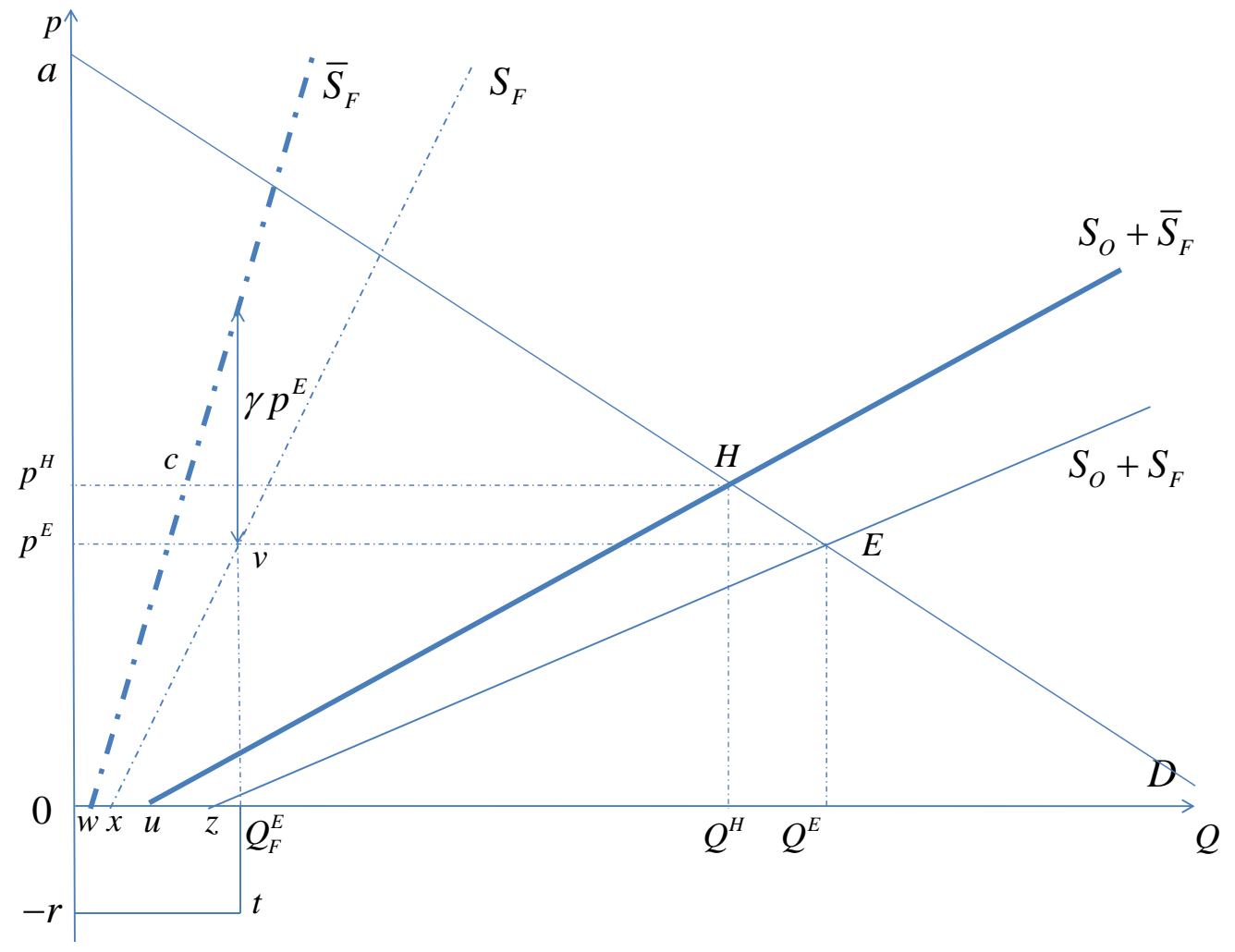

Figure 1. Impact of a standard with unaware consumers $(I=0)$ 


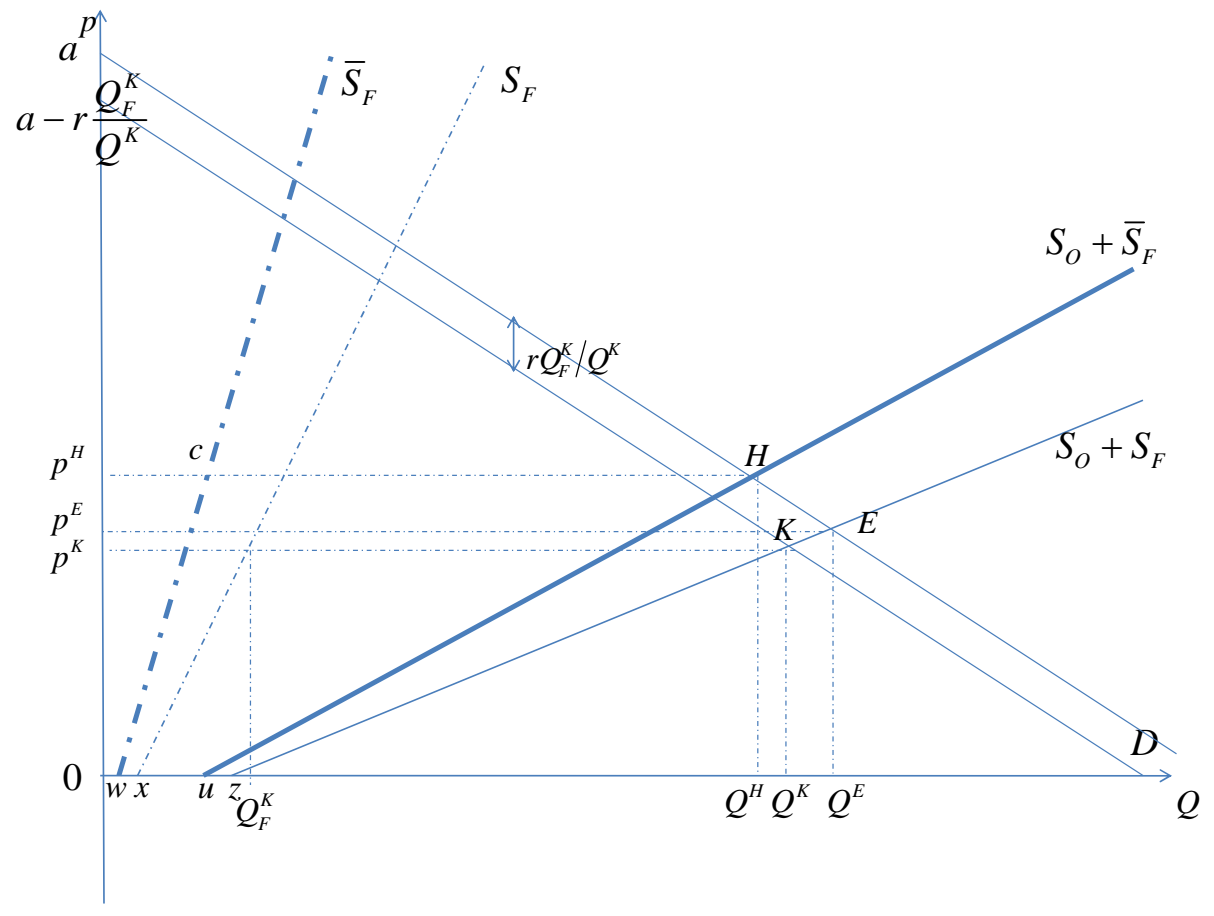

Figure 2. Impact of a standard with aware consumers $(I=1)$ 